\title{
Vertical and Lateral Bearing Capacity of FRP Composite Sheet Piles in Soft Soil
}

\author{
Zhe Wang $\mathbb{D}^{1},{ }^{1}$ Shuwei Wu $\mathbb{D}^{1},{ }^{1}$ Kaiwen Weng $\left(\mathbb{D},{ }^{1}\right.$ Wangjing Yao $\mathbb{D},{ }^{1}$ Sifa Xu $\mathbb{D},{ }^{1}$ \\ and Zhouxiang Ding $\mathbb{D D}^{2}$ \\ ${ }^{1}$ Department of Geotechnical Engineering, Zhejiang University of Technology, Hangzhou 310014, China \\ ${ }^{2}$ Department of Mechanical Engineering, University of Saskatchewan, Saskatoon, SK, S7N5A9, Canada \\ Correspondence should be addressed to Zhouxiang Ding; dingzhouxiang@163.com
}

Received 16 December 2019; Revised 30 August 2020; Accepted 2 September 2020; Published 8 October 2020

Academic Editor: Jia-wen Zhou

Copyright (c) 2020 Zhe Wang et al. This is an open access article distributed under the Creative Commons Attribution License, which permits unrestricted use, distribution, and reproduction in any medium, provided the original work is properly cited.

\begin{abstract}
Fiber-reinforced polymer (FRP) composite sheet piles are usually favored for slope and river-retaining structures due to their construction and environmental efficiency. Their applications, however, have been hindered by the lack of understanding of the bearing capacity. This paper studies the vertical and lateral bearing capacity of FRP composite sheet piles through three full-scale tests conducted in Haiyan, a soft soil site in the Yangtze River Delta of China. In the three tests, we measured the vertical bearing capacity of the FRP composite sheet piles, the bearing capacity of the composite foundation, and the lateral capacity of the FRP composite sheet piles, respectively. The test results show that the Q-S (load on the top of the pile versus settlement) curve of the FRP composite sheet piles exhibits a steep fall while that of the composite foundation is relatively flat. Moreover, the ultimate bearing capacity of the FRP composite sheet piles is measured to reach $23.8 \mathrm{kN}$ while that of the composite foundation increases by $47.1 \%$, reaching $35.0 \mathrm{kN}$. It shows that the FRP composite sheet piles under the composite foundation have a favorable bearing performance. Finally, the final horizontal displacement of the FRP composite sheet pile in the reinforced area with anchoring the sheet pile is smaller than the final horizontal displacement in the nonreinforced area, indicating that the horizontal bearing capacity can be significantly improved by anchoring the sheet pile.
\end{abstract}

\section{Introduction}

Steel sheet pile cofferdams have been widely used for river and coastal revetments, piers, and other support structures built in the water because of their convenience of installment, cost efficiency, and reusability. Research has been conducted into the applications of steel sheet piles [1-4]. The problem of corrosion was found in those steel sheet piles exposed to the marine environment [5-7]. As Zyka and Mohajerani [8] pointed out, the repair and replacement of those piles were costly. To prevent corrosion, solvent or heavy metal coatings were applied to those steel piles, which have serious environmental consequences [9]. Therefore, it is necessary to find a substitute for the steel sheet piles.

The advantages of FRP composite sheet piles over steel sheet piles lie largely in their lightness, high specific strength, high durability, corrosion resistance, chemical resistance, and low maintenance [10-12]. Consequently, FRP composite piles may be employed to replace traditional steel piles under harsh environmental conditions [13]. Despite the disadvantages of FRP composite steel piles-such as high production cost and low material strength, they can be promisingly addressed with technological development $[14,15]$. Moreover, the FRP composite piling provides an effective alternative to recycling solid plastic waste [16]. FRP composite sheet piles tend to be more affordable as they have been more widely adopted in construction [17].

Moreover, the research on the bearing capacity of FRP composite sheet piles has been undertaken from theoretical and experimental perspectives, respectively. On the theoretical side, Momeni et al. $[18,19]$ proposed a novel prediction model based on artificial neural network and pointed out that the geometric characteristics of pile foundations and construction parameters of pile driving were the main 
factors that affect the results of the prediction model. Further, Rezaei et al. [20] developed an improved artificial neural network for the thin-walled shallow foundation prediction model and verified the feasibility of the model through laboratory experiments; Momeni et al. [21] introduced the ANFIS model to estimate the bearing capacity of thin-walled foundations and validated the reliability of the model through field test data. On the experimental side, Giroux and Shao [22] studied the flexural and shear rigidity of composite sheet piles, where Bank's multispan approach and Timoshenko's beam theory were used and bending tests were carried out for multiple span lengths. Their experimental methods provide standards for the field testing. Moreover, it is established that the shear rigidity was more significant than flexural rigidity. Shao and Shanmugam [23] examined the moment capacities and deflection limits of single U-shaped, connected, and concrete-backfilled panels under uniformly distributed load. They found that the single-panel FRP pile capacity was $15 \%$ higher than that of the connection plate, and the concrete-backfilled hybrid panels showed higher bending resistance. This study suggested that pile damage occurs mainly to the flange-web junction. Wang et al. [24] investigated the influences of transverse and longitudinal fiber volume fraction on the flexural behavior of FRP composite sheet pile. The results indicate that increasing the fiber transverse and longitudinal volume fraction is useful for the tearing failure control at the flange-web junction on the compressive side, thus improving the load capacity and the flexural rigidity of FRP composite sheet piles. In addition to the pile foundation's material and design, such factors as the interface contact characteristics of the pile and the soil, the periodic load on the pile foundation, and the long-term cyclic load are also important because they affect considerably the bearing performance. For the sand-pile interface friction, Sakr et al. and Pando et al. $[10,25]$ reported that the interface shear behavior was largely affected by the interface hardness and friction angle. El Sharnouby and El Naggar [26] found that the composite sheet piles, subjected to axial one-way cyclic and monotonic loads, maintained or increased their stiffness and bearing capacity. Yuan et al. and Dutta and Vaidya $[27,28]$ investigated the impact of long-term freeze-thaw cycles on FRP composite sheet piles. The results show that low temperature usually enhances the stiffness and shear strength properties, whereas the impact strength decreases slightly. The existing studies on FRP composite sheet piles largely focus on the properties of single piles but few involve full-scale tests, especially in soft soil. Without reliable design specifications for practical engineering projects, the applications of FRP composite sheet piles may cause some unexpected engineering problems or unnecessary waste.

To study the bearing capacity of a single pile, we pay attention to the differences in material properties. While for the field applications, we highlight their differences from laboratory tests and account for the influence of soil properties on the bearing capacity of the pile. Hence, this paper will present measured data on the bearing capacities of both single FRP composite pile and composite foundation in soft soil. Three fullscale tests will be implemented on the vertical bearing capacity of the piles, bearing capacity of the composite foundation, and lateral bearing capacity of the piles, respectively.

Furthermore, this paper will report a new reinforcement measure-sheet pile anchor-for the situations in which the FRP composite sheet piles undergo considerably large lateral displacements. Conventional reinforcement measures like the anchorage of anchors have the shortcoming of wasting land resources [29], thus necessitating a novel alternative. Through the third full-scale test we conducted, the good performance of the sheet pile anchor will be demonstrated.

\section{Geological Conditions and Test Materials}

2.1. Properties of Test Soil. The geological conditions of engineering interest in various developed countries and regions-like the Yangtze River Delta, an economic center of China-are usually characterized by soft soil. In this study, Haiyan in the Yangtze River delta is our testing site which comprises three soil layers: the plain-fill layer with a top elevation of $1.54-1.92 \mathrm{~m}$ and thickness of $0.70-1.10 \mathrm{~m}$; the clay layer with a top elevation of $0.82-0.99 \mathrm{~m}$ and thickness of $1.70-2.10 \mathrm{~m}$; and the mucky silty clay layer with a top elevation of $-1.16 \sim-0.88 \mathrm{~m}$ and thickness of $2.70-2.90 \mathrm{~m}$. The last layer was not drilled and its maximum entry depth is $7.80 \mathrm{~m}$. According to the Standard for Soil Test Method [30], the specific parameters of the soil layers are obtained, as listed in Table 1. The geological profile of the project site is illustrated in Figure 1.

\subsection{Basic Parameters of FRP Composite Sheet Piles}

2.2.1. Pile Type. The FRP composite sheet piles are U-shaped and nestable with the prescribed pile width $L_{0}(772 \mathrm{~mm})$ and average thickness $D(6 \mathrm{~mm})$; see Figure 2 . Therefore, the effective width $L$ is $L=L_{0}-2 \times D=760 \mathrm{~mm}$. The basic elastic properties of the pile material are listed in Table 2.

2.2.2. Pile Length. The pile lengths for the three full-scale tests are 5.1, 5.0, and $3.5 \mathrm{~m}$, respectively. For Test 1, the lengths of the piles above and below the ground surface are 0.1 and $5 \mathrm{~m}$ long, respectively. The $0.1 \mathrm{~m}$ pile on the surface of the ground is to prevent experimental errors caused by direct contact between the bearing plate and the soil. In Test 2 , all piles are completely buried underground with their top surfaces flush with the ground surface. These 5-meter-long piles penetrate through the plain-fill and clay layers, using the mucky silty clay layer as the bearing stratum. For Test 3, the lengths of the piles above and below the ground surface are 1.5 and $2 \mathrm{~m}$ long, respectively; the bottoms of the piles are located in the clay layer. Figure 3 illustrates the layout of our field testing on the lateral bearing capacity of FRP composite sheet piles.

\section{Methodology for the Full-Scale Tests}

In order to study the vertical and lateral bearing performance of FRP composite sheet piles, three full-scale tests are carried out in this paper. Test 1 obtains the vertical bearing capacity of FRP composite sheet piles in soft soil, Test 2 obtains the vertical 
TABLe 1: Physical and mechanical parameters of soil layers.

\begin{tabular}{|c|c|c|c|c|c|c|}
\hline Soil & Statistics & Water content $w(\%)$ & $\begin{array}{c}\text { Density } \rho \\
\left(\mathrm{kg} / \mathrm{m}^{3}\right)\end{array}$ & Elasticity modulus $E(\mathrm{MPa})$ & Cohesion $c(\mathrm{kPa})$ & Friction angle $\varphi\left({ }^{\circ}\right)$ \\
\hline Plain-fill & Mean & & 1840 & 16.6 & 10.0 & 12.0 \\
\hline \multirow{3}{*}{ Clay } & Mean & 29.5 & 1926 & 24.3 & 32.9 & 19.8 \\
\hline & Maximum & 37.1 & 1980 & 27.2 & 37.2 & 24.4 \\
\hline & Minimum & 25.4 & 1852 & 17.5 & 21.0 & 15.4 \\
\hline \multirow{3}{*}{ Mucky silty clay } & Mean & 38.4 & 1798 & 19.3 & 15.7 & 14.4 \\
\hline & Maximum & 44.4 & 1842 & 33.1 & 20.3 & 17.4 \\
\hline & Minimum & 32.9 & 1744 & 2.28 & 12.8 & 11.4 \\
\hline
\end{tabular}

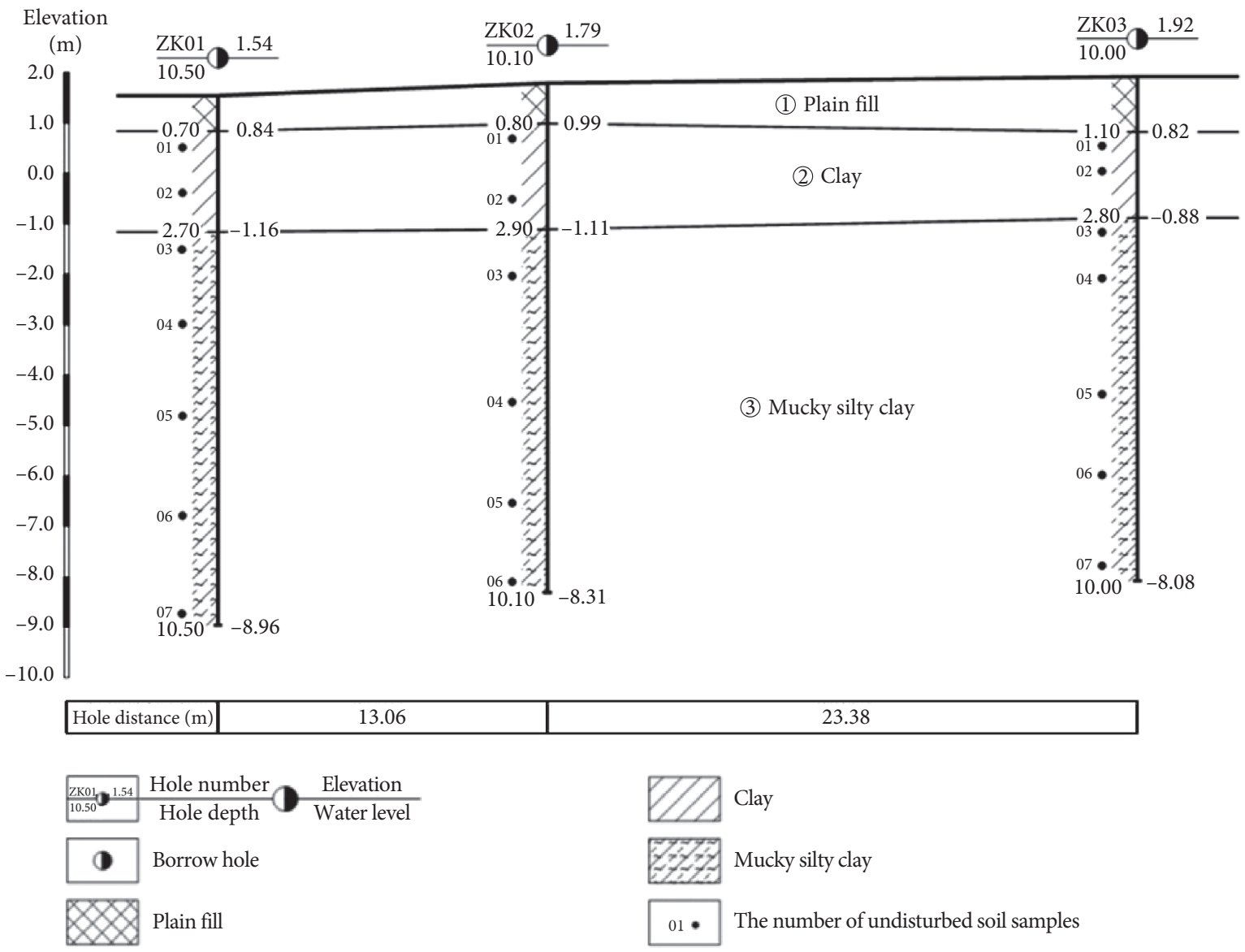

FIgURE 1: The geological cross section of the project site.

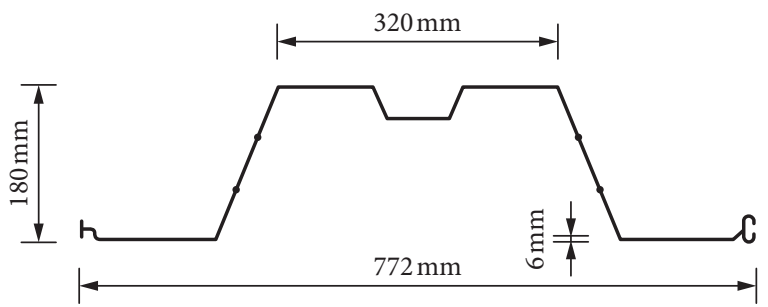

FIGURE 2: Geometry of FRP composite sheet piles.

bearing capacity of FRP composite sheet piles under composite foundation, and Test 3 obtains the lateral bearing capacity of FRP composite sheet piles in soft soil. Among them, Test 1 is carried out in soft soil, Test 2 is carried out in composite foundation, both of which adopt the vertical loading method, and Test 3 is carried out in soft soil using the horizontal loading method. The three full-scale tests presented here are conducted according to China's technical specifications: GB 50007-2011 [31], JGJ 106-2014 [32], and GB/T 50783-2012 [33] for Tests 1 and 2 and JGJ 79-2012 [34], JGJ 106-2014 [32], and GB 500072011 [31] for Test 3, respectively. Figure 4 shows the field testing on the vertical bearing capacity of FRP composite sheet piles.

3.1. Testing of Vertical Bearing Capacity for FRP Composite Sheet Piles. Due to the difficulty in determining the centroid of a single pile in a full-scale test, we utilized a square pile group consisting of four single piles for the static load test. The configuration of the pile foundation is shown in Figure 5. 
TABLE 2: Basic material properties of the FRP composite sheet piles.

\begin{tabular}{|c|c|c|c|c|}
\hline Density $\rho\left(\mathrm{kg} / \mathrm{m}^{3}\right)$ & $\begin{array}{c}\text { Young's modulus (tension) } \\
E_{1}(\mathrm{GPa})\end{array}$ & $\begin{array}{l}\text { Young's modulus (compression) } \\
\qquad E_{2}(\mathrm{GPa})\end{array}$ & Shear modulus $G(\mathrm{GPa})$ & Poisson's ratio $v$ \\
\hline 1549 & 31.4 & 27.8 & 3.1 & 0.18 \\
\hline
\end{tabular}

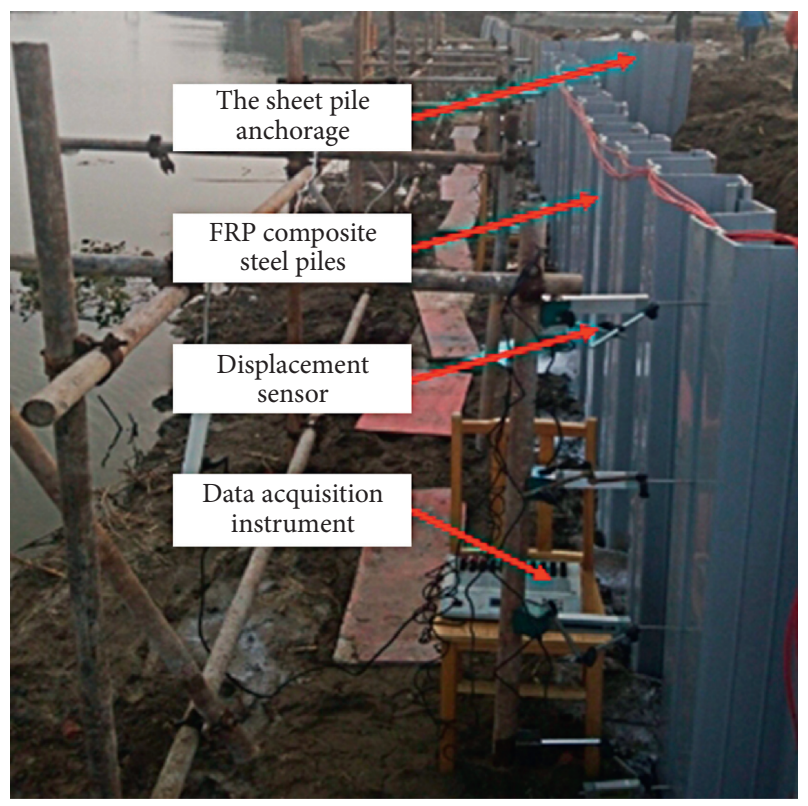

FIGURE 3: Lateral bearing capacity of FRP composite sheet piles for field testing.

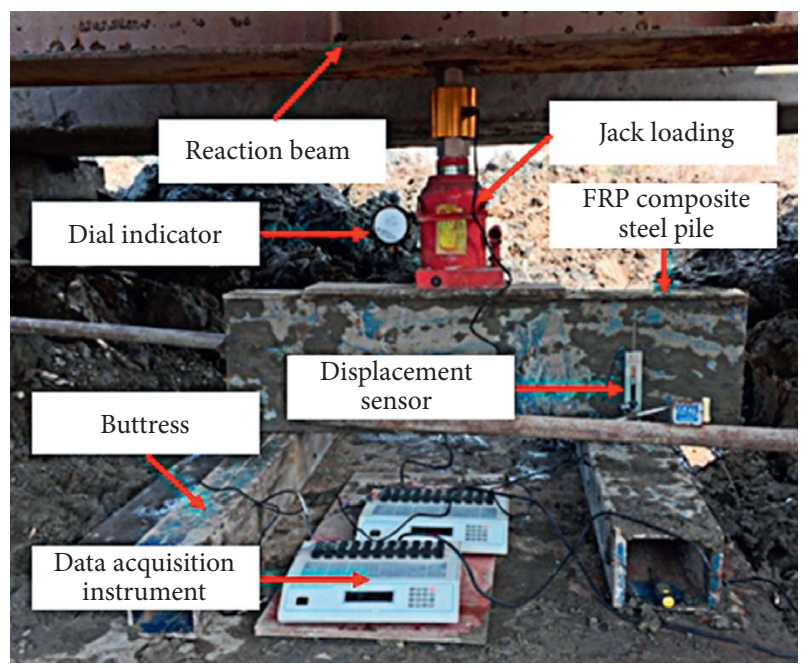

FIGURE 4: Vertical bearing capacity of FRP composite sheet piles for field loading testing.

The schematic diagram of the static load testing is given in Figure 6. The total length of each pile for Test 1 is $5.1 \mathrm{~m}$, of which $5 \mathrm{~m}$ is embedded in the ground. The embedded portion of each pile penetrates through the 0.9-meter-thick plain-fill layer and 2.85-meter-thick silt layer and finally into the mucky silty clay layer-designed as the bearing stratum-by $1.25 \mathrm{~m}$. This testing includes two procedures concerning loading and unloading.

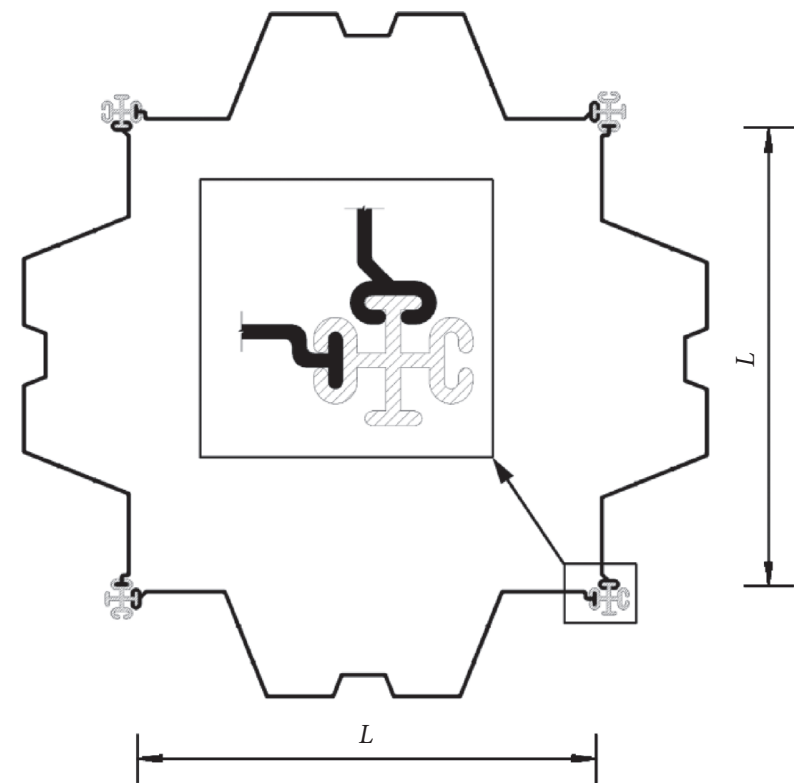

Figure 5: Configuration of the pile foundation for Test 1.

The maximum load for Test 1 is $145 \mathrm{kN}$. The load is divided into 7 levels for loading and 4 levels for unloading. The pile top settlements are measured at the $5^{\text {th }}, 15^{\text {th }}, 30^{\text {th }}$, and $60^{\text {th }}$ minute after each loading is completed. The next level of loading is applied when the deformation under the current load develops almost inappreciably-the differences between two consecutive readings are less than $0.1 \mathrm{~mm}$.

3.2. Static Load Testing on FRP Composite Sheet Piles Foundation. Following the vertical static load testing on the composite piles (Test 1), we conducted the static load testing on the composite foundation comprising mainly the piles and foundation soil (Test 2). As Test 2 still encounters the difficulty in determining the single pile centroid, we managed to employ the scheme of two pile rows with each row composed of three connected piles (see Figure 7). Figure 7 illustrates the effective width of each single pile $L(760 \mathrm{~mm})$ and the space between the piles $H(1100 \mathrm{~mm})$.

The schematic diagram of Test 2 for the composite foundation is shown in Figure 8. The piles for this test are $5 \mathrm{~m}$ long in total and completely embedded underground-through both the 0.95-meter-thick plain-fill layer and the 2.80-meter-thick silt layer, into the bearing stratum (mucky silty clay) by $1.25 \mathrm{~m}$. Our composite foundation plate load test follows the Technical Specification for Composite Foundations [33]. To leverage the synergy between the piles and soil ground to support the vertical load, the $50-150 \mathrm{~mm}$ medium-coarse sand cushion should be set under the bearing plate. Therefore, the pile tops are designed to be flush with the ground surface and covered by 


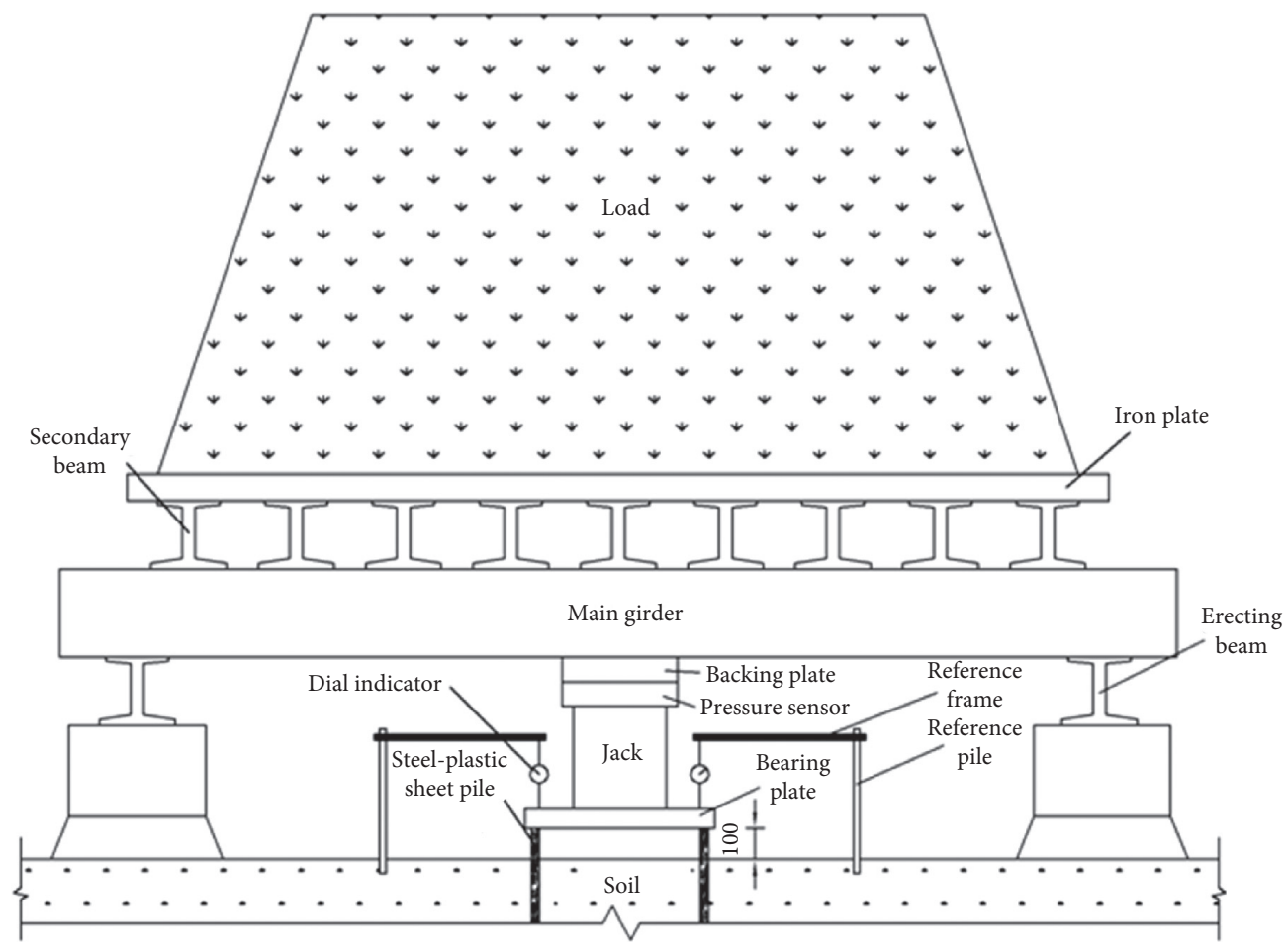

FIgURE 6: Schematic diagram of the static load for Test 1.

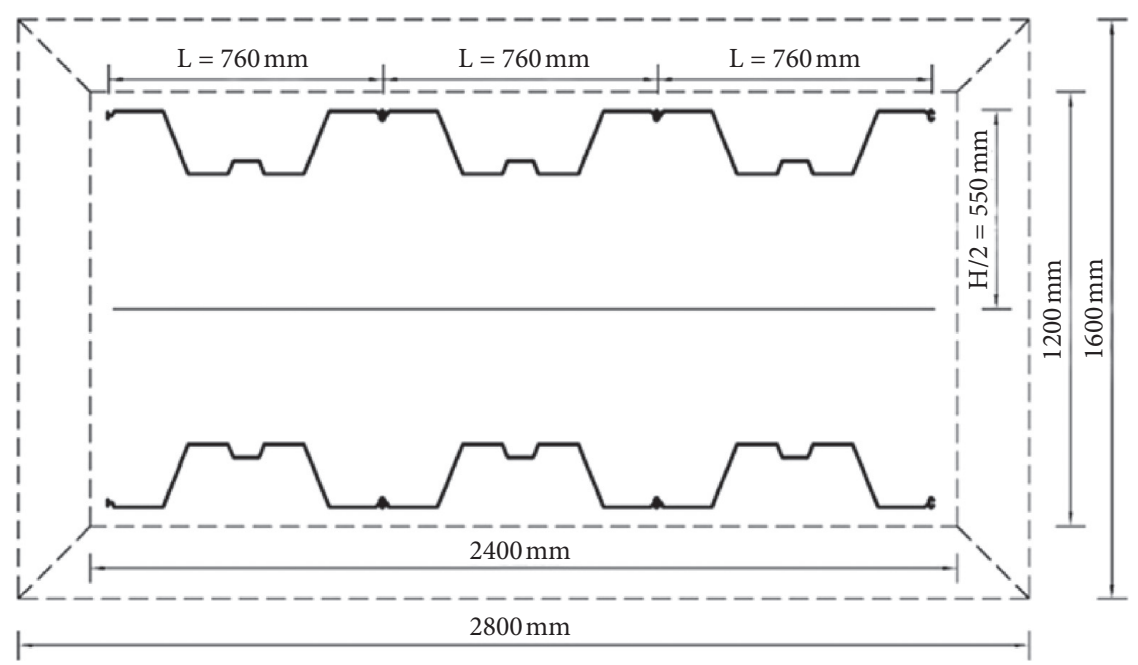

FIgURE 7: Layout of the piles for Test 2.

a 0.1 -meter-thick sand cushion. The plane layouts for the sand cushion bottom and top are 2.8 by $1.6 \mathrm{~m}$ and 2.4 by $1.2 \mathrm{~m}$, respectively, as shown by the dotted line in Figure 7 . The sand cushion has four lateral sides graded by $1: 2$ (see Figure 8 ) and a centroid coinciding with that of the FRP composite sheet piles.

The maximum load for Test 2 is $275 \mathrm{kN}$. This load is divided into 8 levels for loading and 4 levels for unloading. The settlements at the pile top are measured at likewise specified time in Test 1 . The criterion to apply the next level of loading is also identical to Test 1 .
3.3. Testing of the Lateral Bearing Capacity of FRP Composite Sheet Piles. The configuration for Test 3 is principally composed of 24 FRP composite sheet piles, as shown in Figure 9. The first 22 of those piles are distributed along the $x$-axis direction. The sheet pile anchor is provided at the junction of the $16^{\text {th }}$ and $17^{\text {th }}$ piles, by virtue of arranging the $23^{\text {rd }}$ and $24^{\text {th }}$ piles in the $y$ axis direction. All the piles for Test 3 have the same length of $3.5 \mathrm{~m}$ and an underground embedded depth of $2 \mathrm{~m}$. The embedded portions run through the plain-fill layer $(0.85-0.95 \mathrm{~m}$ thick) and into the mucky silty clay layer by $1.05-1.15 \mathrm{~m}$. 


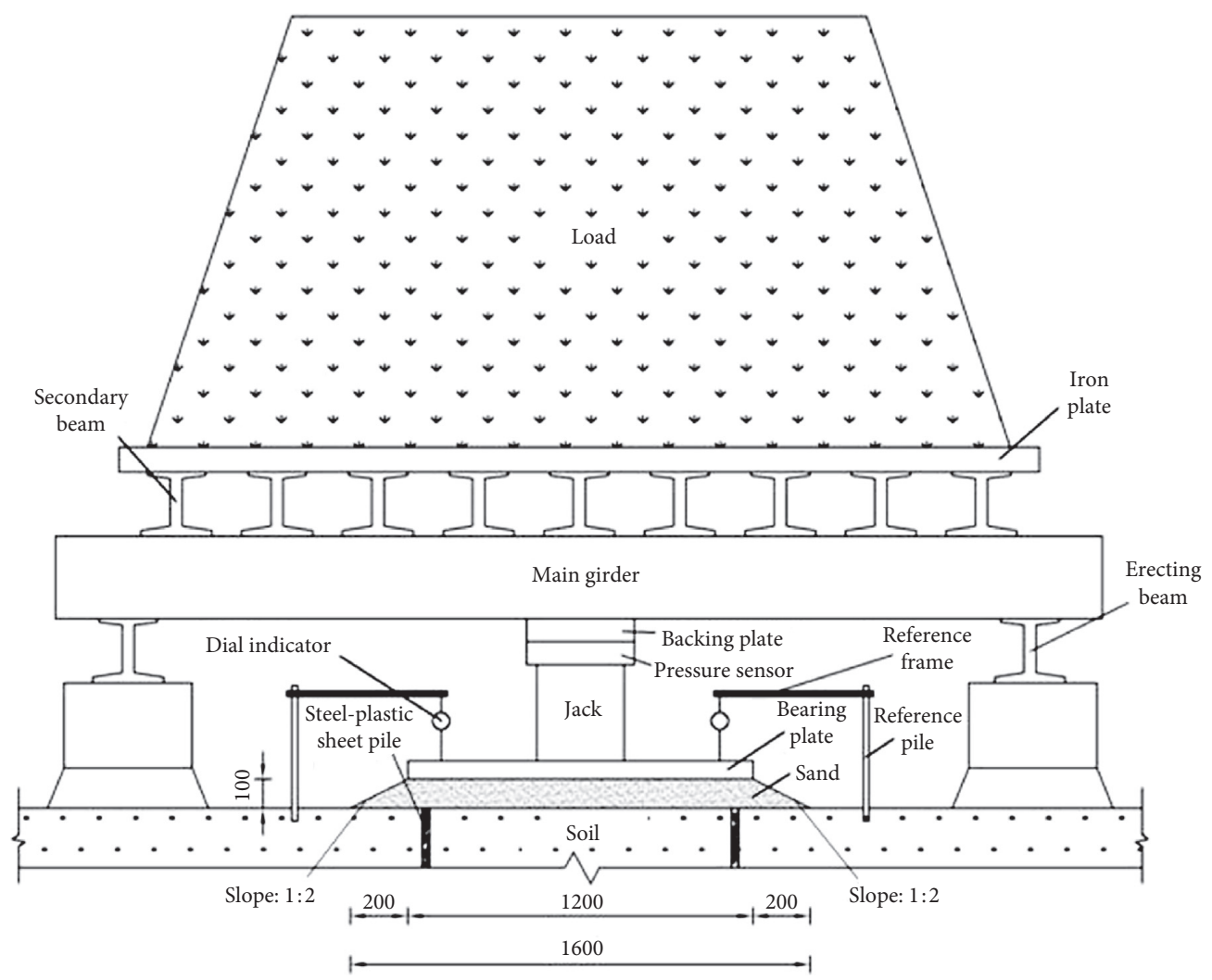

Figure 8: Schematic diagram of the static load testing for Test 2.

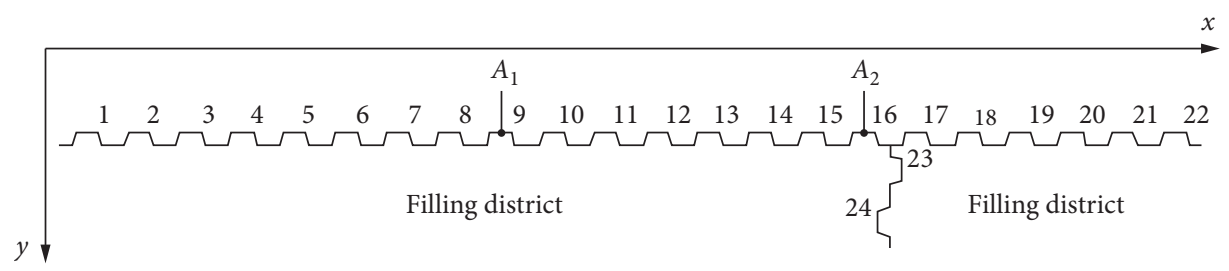

Figure 9: Layout of the piles for Test 3.

FRP composite sheet piles at work are mainly subject to the lateral Earth pressure. To examine the deformation of the piles under Earth pressure, two observation areas $A_{1}$ and $A_{2}$ are selected (see Figure 9). In each area, four displacement gauges are arranged from the bottom up: $a, b, c$, and $d$, as shown in Figure 10. Test 3 involves the following two stages: layered land filling and foundation treatment. The first stage-layered filling-addresses three fillings, each of which is $500 \mathrm{~mm}$ high. The ground surface is thus level with the pile tops. The deformation is measured subsequently for each stable filling. The second stage-foundation treatment-deals with the manual leveling and digging machine rolling. According to the Technical Code for Testing of Building Foundation Piles [32], the next stage of testing can be carried out when the horizontal displacement of FRP sheet piles is less than $0.1 \mathrm{~mm}$ per $60 \mathrm{~min}$. The corresponding lateral displacement is determined when the horizontal displacement of FRP sheet piles is reduced to be less than $0.1 \mathrm{~mm}$ per $20 \mathrm{~min}$.

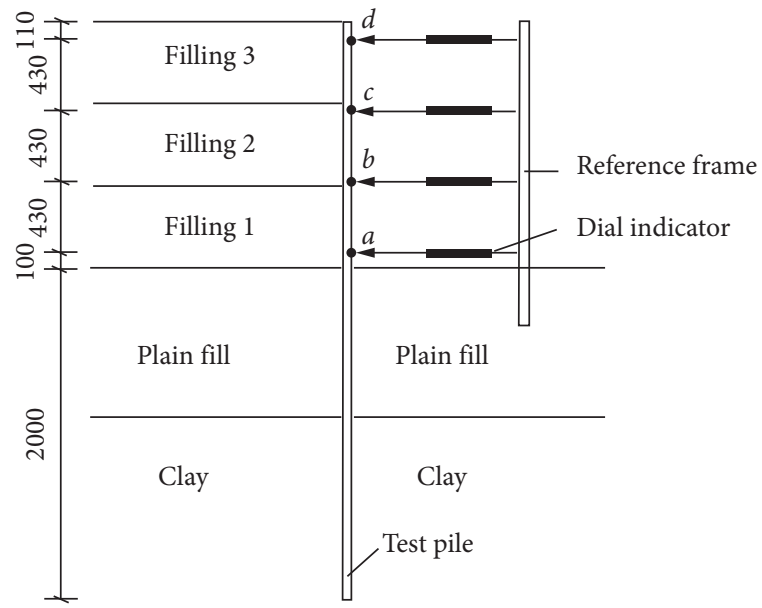

FIGURE 10: Layout of the displacement meters. 
Therefore, we calculated a set of horizontal displacement data for the process of foundation treatment, the horizontal displacement of $A_{1}$ (nonreinforced area) and $A_{2}$ (reinforced area) sections at different depths $a, b, c, d$, respectively. In total, 7 groups of FRP composite sheet pile displacement data are recorded for Test 3:

(a) Group $0\left(\mathrm{G}_{0}\right)$ : initial lateral displacement of FRP composite sheet piles where the initial data are zeroed out (the other groups of data are the corresponding readings minus the initial readings)

(b) Group $1\left(G_{1}\right)$ : lateral displacement of FRP composite sheet piles after the $1^{\text {st }}$ filling

(c) Group $2\left(\mathrm{G}_{2}\right)$ : lateral displacement of FRP composite sheet piles after the $2^{\text {nd }}$ filling

(d) Group $3\left(\mathrm{G}_{3}\right)$ : lateral displacement of FRP composite sheet piles after the $3^{\text {rd }}$ filling

(e) Group $4\left(\mathrm{G}_{4}\right)$ : lateral displacement of FRP composite sheet piles after manual leveling

(f) Group $5\left(\mathrm{G}_{5}\right)$ : lateral displacement of FRP composite sheet piles after digging machine rolling

(g) Group $6\left(\mathrm{G}_{6}\right)$ : final lateral displacement of FRP composite sheet piles

\section{Results}

4.1. Vertical Bearing Capacity of FRP Composite Sheet Piles (Test 1). Figure 11 shows the settlements of the square pile group consisting of $4 \mathrm{FRP}$ composite sheet piles during vertical loading and unloading. The Q-S curve in this figure slopes downward at an increasing rate. During the loading process, the slope of the curve increases significantly after $95 \mathrm{kN}$ (with the corresponding settlement of $25.2 \mathrm{~mm}$ ). In this state, the FRP composite sheet piles are conventionally assumed to reach the ultimate load. For the convenience of testing, the upper 0.1meter-long pile is exposed in the air in the process of pile installation. However, since the measured pile top settlement $(25.2 \mathrm{~mm})$ was far less than $0.1 \mathrm{~m}$, the loading test continued. The maximum load $(145 \mathrm{kN})$ corresponds to the maximum settlement $(93.4 \mathrm{~mm})$. The absolute value of the slope of the unloading curve increases with a decreasing load. At the final stage of unloading, the maximum rebound value reaches $16.9 \mathrm{~mm}$ and the rebound rate (the ratio of the rebound value to the maximum settlement under the current load level) approaches approximately $18.1 \%$.

4.2. Results of Static Load Testing on Pile Composite Foundation (Test 2). Figure 12 shows the loading/unloading settlements of the composite foundation consisting of 6 composite sheet piles and soft soil. The maximum settlement obtained in this testing is $79.4 \mathrm{~mm}(15.0 \%$ lower than Test 1$)$ while the maximum rebound is $21.0 \mathrm{~mm}(24.2 \%$ higher than Test 1). The rebound rates of each load are 2.1, 3.0, 3.4, and $17.9 \%$, respectively. Therefore, the largest rebound (accounting for $67.8 \%$ of the total rebound) occurs at the last unloading level. We also notice that the Q-S curve for this test is smooth and flat: the settlement increases evenly as the load

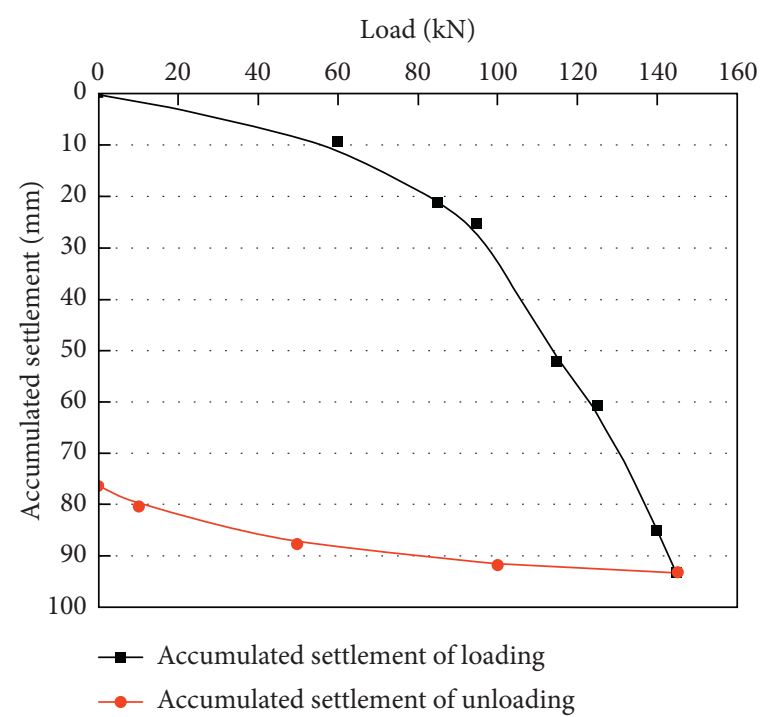

Figure 11: Accumulated settlement under vertical load for Test 1.

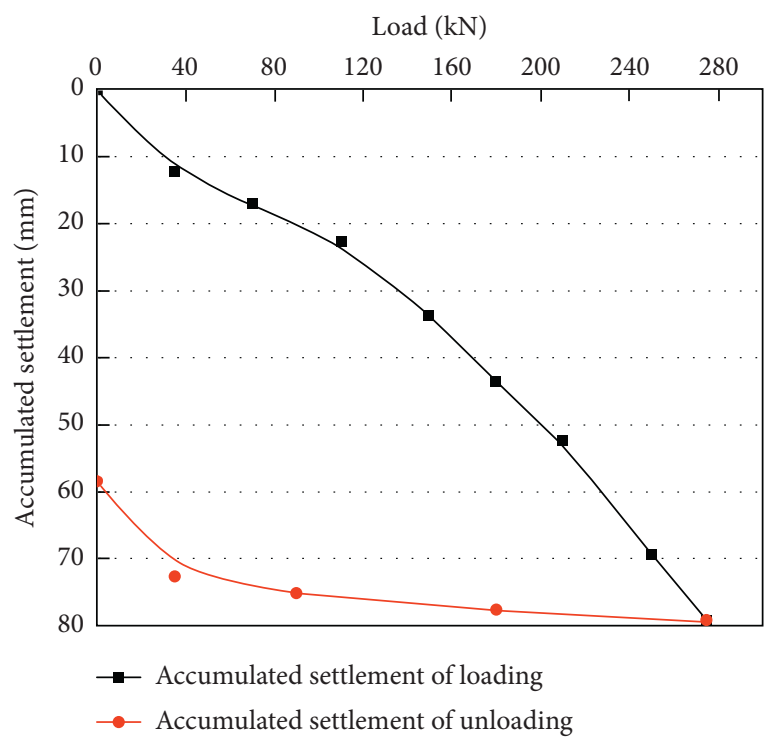

FIgURE 12: Accumulated settlement under vertical load for Test 2.

increases-slightly different from the $Q-S$ curve for Test 1 . This is probably due to the differences between the soil properties. Further, when the load is increased to 210 and $250 \mathrm{kN}$, the corresponding displacements are 8.8 and $16.9 \mathrm{~mm}$, respectively. According to the Technical Code for Testing of Building Foundation Piles [32] and the Technical Specification for Composite Foundations [33], the ultimate bearing capacity in the pile load test is referred to as the prior load level preceding the subsequent load level under which the pile top settlement exceeds twice that of the prior load level and the relative stability standard fails to be met in $24 \mathrm{~h}$. Therefore, the pile foundation is considered to have failed at the application stage of the load $210 \mathrm{kN}$, namely, the composite foundation has correspondingly reached its ultimate bearing capacity. In contrast, the ultimate bearing capacity of the pile foundation for Test 1 is $95 \mathrm{kN}$, far less than the $210 \mathrm{kN}$ for Test 2. The 


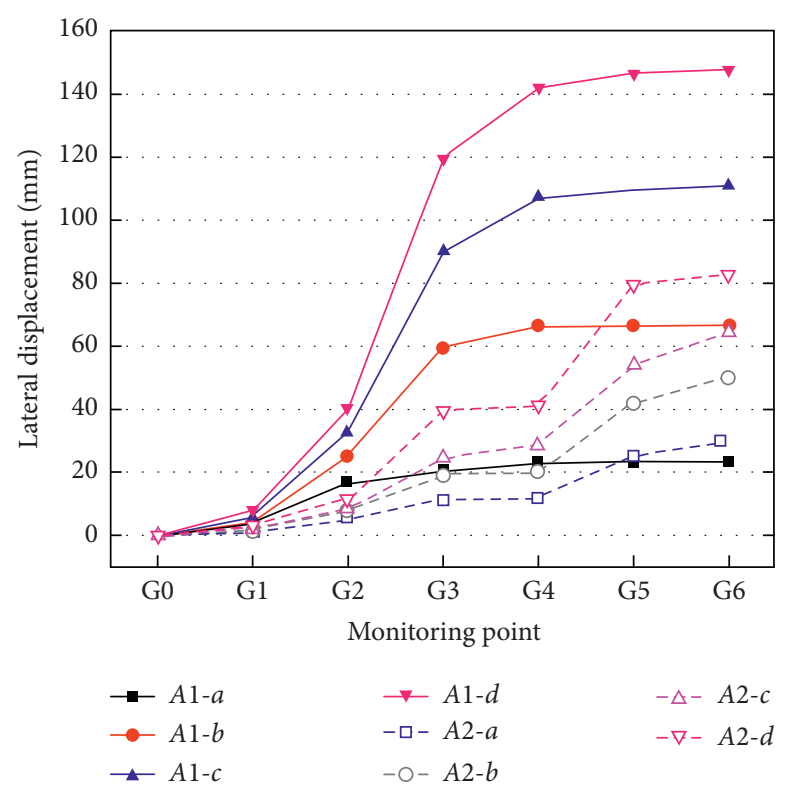

Figure 13: Lateral deformation of the piles in areas $A_{1}$ and $A_{2}$.

reason for this stark difference lies in the mechanism that both the composite foundation and the pile foundation share the load for Test 2, whereas only the pile foundation bears the load for Test 1 . Note that the composite foundation plays a significant role in the comprehensive mechanism of bearing capacity of foundations. As a consequence, the bearing capacity measured for Test 2 is considerably higher than that for Test 1 .

4.3. Results of Testing Lateral Bearing Capacity of FRP Composite Sheet Piles (Test 3). Figure 13 shows the lateral displacements at points $a, b, c$, and $d$ on the FRP composite sheet piles during the filling and foundation treatment stages. Some testing errors unfortunately led to deviations in the test results. Specifically, during $G_{2}-G_{3}$, the reference frame slipped in $A_{1}$, after which we use the plumb bob method for measurement. The final lateral displacements at points $a, b, c$, and $d$ in area $A_{1}$ are 23.5, 66.6, 110.9, and $147.5 \mathrm{~mm}$, respectively. In terms of incremental analysis, points $b, c$, and $d$ in the $A_{1}$ area are featured by the lateral displacement increments in different magnitudes: (1) relatively small for the $G_{0}-G_{1}$ and $G_{4}-G_{6}$ stages; (2) intermediate for the $G_{1}-G_{2}$ and $G_{3}-G_{4}$ stages; (3) relatively large during the $\mathrm{G}_{2}-\mathrm{G}_{3}$ stages. The largest lateral displacement increments account for 51.8, 51.4, and $54.0 \%$ of the total lateral displacement, respectively. On the other hand, the final lateral displacements at points $a, b, c$, and $d$ in area $A_{2}$ are $29.7,50.3,64.5$, and $82.7 \mathrm{~mm}$, respectively. Similarly, points $a, b, c$, and $d$ in the $A_{2}$ area undergo the lateral displacement increments in different magnitudes: (1) relatively small for the $G_{0}-G_{2}, G_{3}-G_{4}$, and $G_{5}-G_{6}$ stages; (2) intermediate for the $G_{2}-G_{3}$ stage; (3) relatively large for the $\mathrm{G}_{4}-\mathrm{G}_{5}$ stage. The corresponding largest lateral displacement increments account for $46.1,43.7,39.1$, and $46.4 \%$ of the total lateral displacement. The rapid increase in the horizontal displacement increments in the $\mathrm{G}_{4}-\mathrm{G}_{5}$ stage may be due to the compaction of the soil by digging machine rolling at this stage. The lateral pressure generated during the compaction process is apparently concentrated on the anchor-pile structure area $A_{2}$ (see Figure 14).

\section{Discussion}

Based on the date of Tests 1 and 2, this paper discusses the vertical bearing capacity of a single composite sheet pile. Figure 15 indicates that, at the onset of the loading process, almost all of the vertical loads are borne by the FRP composite sheet piles. As the vertical load increases, however, the proportion of the vertical load borne by the foundation soil also increases and eventually constitutes $32.0 \%$ of the vertical load. This may be caused by the relatively small cross-sectional area of FRP composite sheet piles so that the piles can incise the soil easily for an increasing load. After the soil failure, the vertical bearing capacity of the piles is mainly sustained by the friction mechanism between the soil and pile surfaces. The maximum bearing capacity $(23.8 \mathrm{kN})$ of the single FRP composite sheet pile corresponds to its settlement of $25.2 \mathrm{~mm}$. The bearing capacity of the composite foundation is $35.0 \mathrm{kN}$ ( $47.1 \%$ higher than that of the single pile) with the corresponding settlement of $52.5 \mathrm{~mm}$. It may be justified that the composite foundation plays a significant role in improving the bearing capacity of the pile foundation.

The basic work principle of the rock-soil anchoring technology may be interpreted as the transfer of applied tensile forces to the surrounding ground, which exhibits its shear strength to resist the tensile force or to stabilize the excavation face [35]. In this paper, we compared the lateral displacements in $A_{1}$ and $A_{2}$ (the average of 4 horizontal displacements at $a, b, c$, and $d$ ) at all stages under study and noticed that the displacements in $A_{2}$ are reduced by 66.5 , $71.1,67.2,69.8,41.8$, and $34.8 \%$, respectively, as compared 


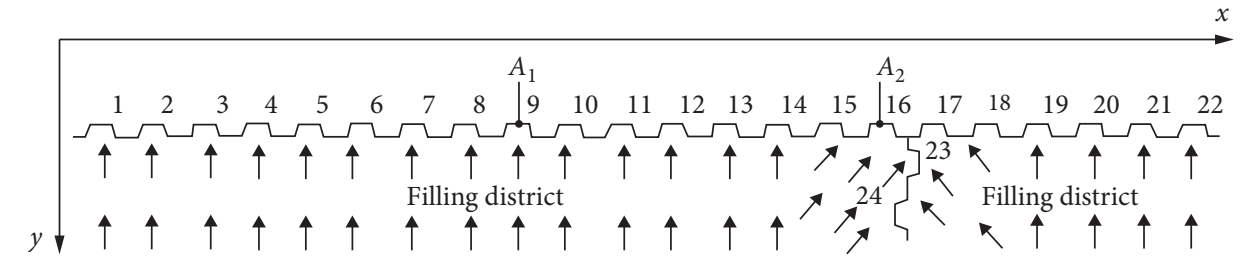

FIGURE 14: Lateral pressure distribution.

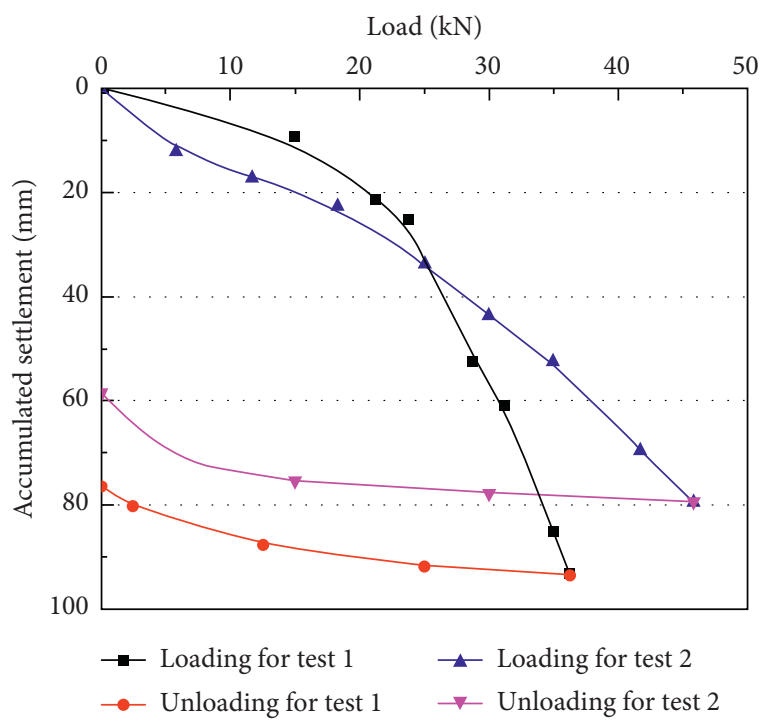

Figure 15: Accumulated settlement of single pile under vertical load.

with the displacements in $A_{1}$. For the FRP composite sheet piles subjected to lateral Earth pressure, the mechanical occlusion occurs between the pile and the soil, owing to the sheet pile anchorage adjacent to the $A_{2}$ area. This effect may determine the pile-soil contact mode to appreciably improve the lateral resistance of sheet piles in this area-further resulting in the enhanced mechanical properties of the soil around the pile and the improved ultimate bearing capacity of sheet piles.

\section{Conclusion}

The FRP composite sheet pile is a novel pile type outweighing conventional steel sheet piles. We studied the bearing performance of FRP composite sheet piles using three full-size field tests in which such parameters as bearing capacity, vertical displacement, and horizontal displacement were observed and analyzed. The following main conclusions may be drawn:

(1) In terms of the vertical bearing performance, the Q-S curve of a single FRP composite sheet pile in soft soil is steep, and the Q-S curve of a single composite sheet pile under the composite foundation is smooth. This is the result of the composite foundation sharing the load. And the vertical ultimate bearing capacity of a single FRP composite sheet pile under the composite foundation is significantly greater than that of a single FRP composite sheet pile in soft soil. Moreover, the cumulative settlement of a single FRP composite sheet pile in soft is comparatively large during the loading process, indicating that the FRP composite sheet piles under the composite foundation have a favorable bearing performance. In soft soil sites, the FRP sheet piles can be effectively reinforced with the composite foundation to meet the high requirements of bearing capacity.

(2) In terms of horizontal bearing performance, the FRP composite sheet piles of the reinforced area possess the final horizontal displacement smaller than that of the nonreinforced area, indicating that the horizontal bearing capacity can be appreciably improved by the anchoring of sheet piles. Furthermore, at the digging machine rolling stage, the increment rate of the horizontal displacements increases rapidly, showing that the anchor-pile structure bears an increasing lateral pressure. Therefore, to improve engineering safety, multiple anchor structures may be worth recommendation for the sheet pile design.

\section{Data Availability}

All the supporting data associated with the study are presented in the paper.

\section{Conflicts of Interest}

The authors declare that they have no conflicts of interest regarding the publication of this paper.

\section{Acknowledgments}

The authors gratefully acknowledge the financial support from the Nature Science Foundation of China (no. 51778585). Thanks are also due to Mr. Ji Xu for the arrangement of field test sites and Mr. Jian-dong Wang for the testing guidance.

\section{References}

[1] J. B. Sellmeijer, J. P. A. E. Cools, J. Decker, and W. J. Post, "Hydraulic resistance of steel sheet pile joints," Journal of Geotechnical Engineering, vol. 121, no. 2, pp. 105-110, 1995.

[2] M. P. Byfield and R. J. Crawford, "Oblique bending in U-shaped steel sheet piles," Proceedings of the Institution of Civil Engineers - Structures and Buildings, vol. 156, no. 3, pp. 255-261, 2003. 
[3] Y. Zhu, Q. Y. Gu, J. Jiang, M. Peng, and B. H. Xiao, "Reliability analysis for overall stability of large-span double-row steel sheet-piled dock cofferdam based on Bayesian method," vol. 37, pp. 609-615, 2016.

[4] X. Wang, "Field test investigation of the pile jacking performance for prefabricated square rigid-drainage piles in saturated silt sandy soils," Advances in Civil Engineering, vol. 2019, Article ID 4587929, 11 pages, 2019.

[5] D. Jones, "Principles and prevention of corrosion," Materials \& Design, vol. 14, no. 3, 1996.

[6] R. Lampo, T. Nosker, D. Bamo et al., Development and Demonstration of FRP Composite Fender Loadbearing, and Sheet Piling Systems, US Army Corps of Engineers Construction Engineering Research Laboratories, Champaign, IL, USA, 1998.

[7] H. Wall and L. Wadsö, "Corrosion rate measurements in steel sheet pile walls in a marine environment," Marine Structures, vol. 33, pp. 21-32, 2013.

[8] K. Zyka and A. Mohajerani, "Composite piles: a review," Construction and Building Materials, vol. 107, pp. 394-410, 2016.

[9] M. G. Iskander and A. Stachula, "Wave equation Analyses of fiber-reinforced polymer composite piling," Journal of Composites for Construction, vol. 6, no. 2, pp. 88-96, 2002.

[10] M. Sakr, M. H. El Naggar, and M. Nehdi, "Interface characteristics and laboratory constructability tests of novel fiberreinforced polymer/concrete piles," Journal of Composites for Construction, vol. 9, no. 3, pp. 274-283, 2005.

[11] A. Mohammed, A. Manalo, G. Maranan, Y. Zhuge, P. V. Vijay, and J. Pettigrew, "Behavior of damaged concrete columns repaired with novel FRP jacket," Journal of Composites for Construction, vol. 23, no. 3, pp. 1943-5614, 2019.

[12] C. S. Sirmanna, "Behaviour of fibre composite piles for timber rehabilitation," Dissertation, University of Southern Queensland, Toowoomba, Australia, 2011.

[13] E. Guades, T. Aravinthan, M. Islam, and A. Manalo, "A review on the driving performance of FRP composite piles," Composite Structures, vol. 94, no. 6, pp. 1932-1942, 2012.

[14] R. Heinz, "Plastic piling," Civil Engineering, vol. 63, no. 4, pp. 63-65, 1993.

[15] H. Fang, Y. Bai, W. Liu, Y. Qi, and J. Wang, "Connections and structural applications of fibre reinforced polymer composites for civil infrastructure in aggressive environments," Composites Part B: Engineering, vol. 164, pp. 129-143, 2018.

[16] M. Iskander, "Recent developments in FRP composite piling practice," in Proceedings of the. Transportation Research Board Meeting, Baltimore, MD, USA, September 2002.

[17] M. G. Iskander and M. Hassan, "State of the practice review in FRP composite piling," Journal of Composites for Construction, vol. 2, no. 3, pp. 116-120, 1998.

[18] E. Momeni, R. Nazir, D. Jahed Armaghani, and H. Maizir, "Prediction of pile bearing capacity using a hybrid genetic algorithm-based ANN," Measurement, vol. 57, pp. 122-131, 2014.

[19] E. Momeni, R. Nazir, D. Jahed Armaghani, and H. Maizir, "Application of artificial neural network for predicting shaft and tip resistances of concrete piles," Earth Sciences Research Journal, vol. 19, no. 1, pp. 85-93, 2015.

[20] H. Rezaei, R. Nazir, and E. Momeni, "Bearing capacity of thinwalled shallow foundations: an experimental and artificial intelligence-based study," Journal of Zhejiang UniversityScience A, vol. 17, no. 4, pp. 273-285, 2016.

[21] E. Momeni, D. J. Armaghani, S. A. Fatemi, and R. Nazir, "Prediction of bearing capacity of thin-walled foundation: a simulation approach," Engineering With Computers, vol. 34, no. 2, pp. 319-327, 2017.

[22] C. Giroux and Y. Shao, "Flexural and shear rigidity of composite sheet piles," Journal of Composites for Construction, vol. 7, no. 4, pp. 348-355, 2003.

[23] Y. Shao and J. Shanmugam, "Moment capacities and deflection limits of PFRP sheet piles," Journal of Composites for Construction, vol. 10, no. 6, pp. 520-528, 2006.

[24] J. Wang, W. Liu, R. Liang, G. Hota, and L. Wan, "Analytical and experimental study on flexural behavior of pultruded fibre reinforced polymer sheet piles," Journal of Composite Materials, vol. 50, no. 4, pp. 3415-3429, 2015.

[25] M. Pando, C. Ealy, G. Filz, J. Lesko, and E. Hoppe, "A laboratory and field study of composite piles for bridge substructures," Virginia Transportation Research Council, Charlottesville, VA, USA, 2006.

[26] M. M. EI Sharnouby and M. H. El Naggar, "Axial monotonic and cyclic performance of fibre-reinforced polymer (FRP)steel fibre-reinforced helical pulldown micropiles (FRPRHPM)," Canadian Geotechnical Journal, vol. 49, no. 12, pp. 1378-1392, 2012.

[27] X. Yuan, G. H. Zhu, and L. Yu, "Freeze/thaw durability of carbon fiber reinforced concrete," Applied Mechanics and Materials, vol. 174-177, pp. 816-820, 2012.

[28] P. Dutta and U. Vaidya, "A study of the long-term applications of vinyl sheet piles,” pp. 10-16, Cold Regions Research and Engineering Laboratory, Hanover, NH, USA, 2003.

[29] Y. S. Pang, H. L. Liu, and Y. J. Gong, "Study of pullout tests of recoverable anchors," Yantu Lixue/Rock and Soil Mechanics, vol. 31, no. 6, pp. 1813-1821, 2010.

[30] GB/T 50123, Standard for Soil Test Method, China Architecture \& Building Press, Beijing, China, 1999.

[31] GB 50007-2011, Code for Design of Building Foundation, China Architecture \& Building Press, Beijing, China, 2011.

[32] JGJ 106-2014, Technical Code for Testing of Building Foundation Piles, China Architecture \& Building Press, Beijing, China, 2014.

[33] GB/T 50783-2012, Technical Specification for Composite Foundations, China Architecture \& Building Press, Beijing, China, 2012.

[34] JGJ 79-2012, Technical Code for Ground Treatment of Buildings, China Architecture \& Building Press, Beijing, China, 2012.

[35] A. R. Akisanya and A. Ivanović, "Debonding along the fixed anchor length of a ground anchorage," Engineering Structures, vol. 74, pp. 23-31, 2014. 